\section{The Professional}

By the time this Perspective is printed, another Annual General Meeting and Conference will have been successfully concluded thanks to the efforts of many dedicated volunteers of the Institute. The 1999 Banff AGM was the culmination of a productive year of the CIF/IFC membership. On behalf of the Executive and the Board I would like to thank all the members who participated in many worthwhile projects and initiatives both at the Section and National levels.

Each year, as we prepare for important events such as the Awards Banquet, honouring the remarkable efforts of distinguished forest practitioners, I think about the tireless efforts of so many other forest professionals that too often go unrecognized and are regrettably not in the public eye. One of my personal aims of 1999-2000 is to start a campaign to raise the awareness within the general public of the important contribution that each forest practitioner makes towards resource management and sustainability. The profession of forestry has become incredibly diverse, ranging from forest ecologists to industrial managers, silviculturists to researchers and many others. Each of these fields provides an invaluable contribution towards our common goal, to have a well-managed, healthy forest providing all of the known and yet-tobe discovered benefits to society and the environment.

Taking over from one of those tireless forest professionals, as your President, is a daunting task. As my first duty of 1999-2000, I want to congratulate Evelynne Wrangler, our outgoing President, Ralph Roberts, outgoing Past President, and Roxanne Comeau, our Executive Director, on a year full of accomplishments. It is based upon this success that I have given priority to the following short list of work for the coming year to continue the advancements in achieving our Mission objectives.

My first priority is to have Evelynne work with others to develop a comprehensive Business Plan for the Institute. The Business Plan will focus on our annual budget process, detailing the next two years, and forecasting five years, in line with our strategies and priorities outlined in the Strategic Plan. An annual update of the Business Plan will contribute to the goal of continual improvement and will enable the products of the CIF/IFC to be portrayed and promoted accordingly.

The second priority will be based upon the decisions and recommendations of the Board of Directors in Banff. This work will involve continued movement forward on networking with our sister organizations to develop a "partnership assembly" of like-minded societies dedicated to working cooperatively on common goals. Don Gelinas, our incoming 2nd Vice-president will lead this initiative, following in the footsteps of Gord Stone who will have made a progress report to the Board in Banff. $\triangleright 717$

\section{Le Professionnel}

D'ici à ce que cette édition de Perspective soit imprimée, une autre assemblée générale et conférence annuelles se sera terminée dans le succès grâce aux efforts de plusieurs bénévoles impliqués au sein de l'Institut. L'assemblée annuelle de Banff en 1999 aura été le point d'orgue d'une année productive pour les membres de l'Institut. Au nom des membres de l'Exécutif et du Conseil, je souhaiterais remercier tous les membres qui ont participé à la réalisation de plusieurs projets importants tant au niveau des sections qu'à l'échelle nationale.

Chaque année, tandis que nous nous préparons à des événements importants comme le banquet d'honneur soulignant les efforts remarquables de certains praticiens en foresterie, je songe aux efforts inlassables de plusieurs autres professionnels de la foresterie qui trop souvent ne sont pas reconnus et qui ne sont pas du domaine public. Un des mes principaux objectifs de 1999-2000 est de mettre en place une campagne pour accroitre la sensibilisation du public en général sur la contribution importante de chaque praticien en foresterie en matière d'aménagement des ressources et de durabilité. La profession de forestier est devenue incroyablement diversifiée, allant des écologistes forestiers aux gestionnaires industriels, des sylviculteurs aux chercheurs sans compter plusieurs autres domaines. ChaPresident
timable dans le sens de notre objectif com-
mun, l'obtention d'une forêt bien aménagée procurant tous les President
timable dans le sens de notre objectif com-
mun, l'obtention d'une forêt bien aménagée procurant tous les bénéfices connus et à découvrir à la société et à l'environnement.

Remplacer l'un de ces professionnels de la foresterie travaillant sans répit, comme votre présidente, représente une tâche gigantesque. Ma première tâche en 1999-200 est de remercier Evelynne Wrangler, notre présidente sortante, Ralph Roberts, le président sortant de l'année dernière et Roxanne Comeau, notre directrice exécutive pour cette année remplie d'objectifs atteints. C'est à partir de ces succès que j'ai établi la liste qui suit de buts à atteindre pour la prochaine année afin de poursuivre la réalisation des objectifs de notre mission.

Ma première priorité est de voir Evelynne travailler avec d'autres personnes au développement d'un plan d'affaire détaillé pour l'Institut. Le plan d'affaire portera sur notre processus d'établissement du budget annuel, contenant les détails pour les deux prochaines années, et des prévisions pour les cinq années à venir, et tenant compte de nos stratégies et des priorités soulignées dans le plan stratégique. Une révision annuelle du plan d'affaire apportera une amélioration continue et permettra aux produits de l'Institut d'être définis et diffusés en conséquence.

Ma seconde priorité reposera sur les décisions et les recommandations du conseil d'administration suite à la réunion de Banff. Cet élément comprendra la poursuite du rapprochement avec les organismes du milieu forestier afin d'élaborer $\$ \mathbf{7 1 7}$ 


\section{LETTERS / LETTRES}

\section{World Forestry Congress}

Dear Ms. Wrangler: As you may already know, Canada has been successful in its bid to host the XII World Forestry Congress (WFC) in Québec City in 2003. I would like to take this opportunity to thank you, as a member of the National Forest Strategy Coalition, for supporting Canada's bid to host this important event.

Subsequent to the January 1999 resolution of the coalition to support Canada's bid, Natural Resources Canada and Quebec's Department of Natural Resources prepared candidacy documentation for Canada's submission and presentation to the United Nation's Food and Agriculture Organization (FAO) in March 1999. The FAO Committee on Forestry did not reach a conclusion at that meeting. Therefore, in June 1999 - at the 116th FAO Council meeting in Rome - Canada again presented its proposal to the participants from more than 100 member countries.

Canada was chosen for a number of reasons, not the least of which were the broad support within Canada to host this congress, and the financial and human resources available to support such an endeavour. In addition, Canada's state-of-theart communications technology will facilitate access to information and documentation of the congress proceedings. Québec City will captivate congress participants with its natural beauty and historic sites.

It will be an honour for us all to host the first WFC of the new millennium, in 2003. The WFC is the largest international forum in the field of forestry, bringing together decisionmakers, specialists, industrial leaders and representatives of non-government organizations from all over the world. Canada will certainly become the focal point and reference for all forestry-related issues, especially for the duration of the congress.

As you are no doubt interested in our submission, I have enclosed Canada's candidacy kit for your review. Please join me in providing continued support for this Canadian initiative.

\section{Ralph Goodale Minister of Natural Resources}

Perspective Third, I am anxious to see the framework of forest policies and position statements that the Institute will be developing in the next few years. Having a set of clear and comprehensive policies relating to the values and beliefs of the membership regarding sustainable management is crucial to the promotion of the Institute as a source of valued opinion and recommendations for public, private landowners, and politicians.

While these are three of my personal priorities, I don't want anyone to get the impression that there won't be priority given to many other worthwhile tasks of the Institute. I am specifically referring to the progress made in implementing our Strategic Plan and Communications Plan as well as our Institute's contribution to the National Forest Strategy. And no less effort will be made in maintaining the high caliber of The Forestry Chronicle and the most impressive websites in forestry anywhere.

I am looking forward to the start of the new millennium as the beginning of a new age of forestry, where forest professionals are recognized in society as forest healthcare specialists linked by a common goal of conservation and sustainable management. The coming year will be another year of successful membership participation in the design and efforts of the Institute.

The Executive and Board cannot function without your continued input and dedication. My thanks to you all.

Bruce A. Ferguson R.P.F. President
Perspective « une assemblée des partenaires », des organismes partageant notre vision, tout en cherchant à coopérer sur les objectifs communs. Don Gelinas, notre deuxième vice-président, dirigera ces opérations, tout en suivant les traces de son prédécesseur Gord Stone qui aura déposé un rapport d'étape devant le Conseil d'administration à Banff.

Troisièmement, j'ai hâte de voir le cadre des politiques forestières et des énoncés de position que l'Institut élaborera au cours des prochaines années. Avoir en main un ensemble de politiques claires et globales sur les valeurs fondamentales des membres au sujet de l'aménagement durable, représente un élément crucial de promotion pour l'Institut en tant que source d'opinion reconnue et de recommandations pour le public, les propriétaires de boisés privés et les politiciens.

Même s'il s'agit de trois priorités personnelles, je ne voudrais pas donner l'impression à quiconque qu'il n'y aura pas d'attention accordée à d'autres tâches majeures au niveau de l'Institut. Je fais référence spécifiquement au progrès enregistré dans l'implantation de notre plan stratégique et de notre plan de communication, ainsi qu'à la contribution de l'Institut à la Stratégie nationale sur les forêts. Et aucun effort ne sera épargné pour maintenir le haut niveau de qualité du Forestry Chronicle et des sites Internet les mieux appréciés en foresterie peu importe l'endroit.

Je vise en ce début de millénaire à créer un nouvel âge de la foresterie, où les professionnels de la foresterie seront reconnus par la société en tant que spécialistes de la santé des forêts liés entre eux par un objectif commun de conservation et d'aménagement durable. La prochaine année sera une autre année remplie de succès suite à la participation des membres dans la conception et les efforts de l'Institut.

Le comité exécutif et le conseil d'administration ne peuvent fonctionner sans votre apport et votre implication. Je vous en remercie tous. 